\title{
An Examination of Mass Sporting Event Effects on Local Government Economy: The Case of $41^{\text {st }}$ Istanbul Marathon
}

\author{
${ }^{1}$ Arif Cetin, ${ }^{2}$ Ayca Doganer \\ ${ }^{1}$ Istanbul Sports Events, Istanbul, Turkey. ${ }^{2}$ Istanbul Chamber of Commerce, Istanbul, Turkey.
} Submitted 04 January 2020; Accepted in final form 10 March 2020.

\begin{abstract}
Background. Today, the importance of budget performances has become more evident in the public and local sectors. In terms of transparency and accountability, it is essential to analyses the benefits and costs of the activities supported by the local government budget. Objectives. This study aims to the satisfaction of participants of the Istanbul Marathon is compared with the cost items spent during the organization. Material. The sample of this study consisted of 247 nonresidents, and 1341 resident runners participated by voluntary selection. Methods. Who participated in the 41st Istanbul Marathon. In the research, questions were asked by the participants during or before the Marathon in the questionnaire form. Also, the Likert system with a five-point scale was used in the questions to obtain the participants' experience. The relations between variables are tested with factor analysis and correlation analysis. Results. The results of this study have shown that the most dominant variable among non-resident participants in the cost items in the event process was the start and finish organizations with $82 \%$. Resident participants were found to have chip service with $91 \%$ of the dominant group. Also, prize money is the least dominant variable in the cost process in both non-resident and resident groups. In prize money, it has $47 \%$ in the non-resident group and $49 \%$ in the resident group. Moreover, all other cost items were deemed necessary by the participants between $59 \%$ and $91 \%$. Conclusion. In conclusion, the cost items spent within the scope of the Istanbul Marathon were evaluated by both resident and non-resident participants; it was determined that the lowest factor in both groups was the prize money. The requirement of all other cost items perceived by both resident and non-resident participants is over $50 \%$. Therefore, the local governmentsponsored the Marathon was supported by both non-resident and resident participants, where the principal expenditure items were required.
\end{abstract}

\section{KEYWORDS: Mass Sport Events, Economic Impact, Sport Tourism, Sport Economy, Marathon}

\section{INTRODUCTION}

Today, the importance of budget performances has become more prominent not only in the private sector but also in the public and local. Effective service delivery in local government is also of great importance for the country's economy. Therefore, it is essential to analyse the benefit and cost of the activities sponsored by the local government budget with regards to transparency and accountability. Recreational running activities have become popular in the world, and there is increasing interest and participation in the Marathon, which is among the most popular of these activities (1). The number of runners in road races reaches more than one hundred thousand participants in more than one thousand races worldwide. The number of runners who completed the Marathon in the world in 2016 increased from 138,267 in 2011 to 276,535 in 2016 (2). In recent years both the marathon and road race events in Turkey have become quite popular. Which is one of Turkey's most significant road running event Istanbul Marathon

*. Corresponding Author:

Arif Cetin, $\mathrm{PhD}$

E-mail: arifcetin1985@yahoo.com 
Istanbul Metropolitan Municipality of Istanbul in 2008, according to data while sports participation in 7630 this number increased to 37,000 in 2019 (3).

Sport is not only having crucial cultural importance in the life of modern society but also is become an important industry today. Countries use sports events to promote themselves and their cities, develop their tourism potential and economies (4). Road-running events, such as the Marathon, are becoming an increasingly important instrument for cities to attract tourists from domestically and abroad, the country and encourage economic activity to generate tourism revenue (5). Major events such as the Istanbul Marathon includes participants from more than 100 countries have a potential bear the expenses of extra operational costs. Aside from sport, there is much research that has been done for both variables in the literature. Many studies have been analysed on the economic impacts of the mass sports event. However, there is a minimal number of studies in Turkey. Besides, many sports events are financed by the public in our country. In this case, there are criticisms about whether the public spending on Events is suitable for the purpose. The subject of our research is to the satisfaction of participants of the Istanbul Marathon is compared with the expenditures during the organization.

This study tries to estimate the economic impact of non-resident participants' spending during the 2019 Vodafone Istanbul Marathon event. The first section uses national and international literature to define the concepts of economic impacts of sports tourism. In the second part, empirical data is explained as well as data collection and analysis. Based on these empirical findings, the third section analyses the effect of mass sports events on the local economy. As a result, the discussion summarizes the main findings.

Sport Tourism. Sports tourism has taken its place among many types of tourism and is an activity that climbs to the top of the top step day by day. Sports tourism can be defined as travels that people make to monitor or participate in sports activities by leaving the place where they constantly live for fun (6). In other words, sports tourism is travel and experience to conduct or monitor sports-related activities (7). Sports tourism to discipline that examines the type of tourism consisting of individuals or groups participating in sports activities that may include competition as well as being actively or passively made for fun by travelling to a place outside the place of residence. (8).

Many studies in the field literature deal with international sports organizations and sports tourism and examine these two variables in various aspects. In the first place, however, these efforts often regarded international sports organizations as an essential motivator for tourism and focused on the impact of these organizations on local, regional and national economies $(9,10)$. Initially, studies examining the social, cultural and environmental impacts of such organizations and the perceptions and attitudes of the local society towards these effects were relatively ignored. In the following period, international events; research on its importance, economic, social, political, political advantages, cultural influences, social perceptions and attitudes have increased for the host country, region and city $(11,12)$.

Economic Impact. Candidate cities are working through very sensitive to host mega-sports events. One of the main reasons for this was analysed the economic benefit of the hosting events. Many host cities have supported this process through various infrastructure investments, subsidies and incentives by governments $(13,14)$. The extent of public subsidies, incentives, subsidies and supports have created economic analysis. The size of public funds invested to support sports activities constituted the economic analysis of the sector $(15,16)$. Studies are also available to analyse the economic dimensions of regional and mass sports activities $(5,17)$.

It refers to the net changes in the local economy in the city, which hosts mega or major sports events of the economic impact of sporting events. These net changes include a variety of transactions related to new investments, cost of sporting events, participants' expenses, service purchases, procurement processes (18). The impact of such funds on the local, regional and national economy consists of three components: direct, indirect and stimulated. The direct impact is consist of household expenditures in the economy, household expenditures and savings in non-economy household expenditures and increases in noneconomic expenditures, such as food, shelter, transportation and game tickets by foreign visitors, include injections and leaks in macroeconomic terms such as cross-industry purchases, increasing direct household revenues and government revenues. The indirect effect is consisting of inter-industrial acquisitions for all businesses, household income as a result of secondary activities, government revenues and infiltrations, while the increase in domestic and non-economic household expenditures and savings in the next stage. Finally, it expresses the effects of the increases in household revenues that will emerge with stimulating games on other sectors of the economy. Indirect and exciting effects mentioned here are 
generally combined under the name of secondary effects $(9,19)$.

The impacts of sports events on the general economy are the main objectives of the research. However, a conventional model should be established to predict the economic impact (20). The Input-Output Model or multiplier model was developed by Leontief 1986. This Model is one of the most widely used models in economic impact research. Input-Output model analysis can be defined as "a systematic method for digitizing complex relationship dimensions across various industries (21). The Model's impact on the economy can provide a comprehensive view of investors and organizers as well as analyze the extent of the relationships between various components in the economy. These opportunities provide the Model make a powerful instrument for analyzing the economic impact of sporting events on tourism (2224). This model is used to measure participation costs, accommodation costs, local expenses and other economic benefits during the event. Istanbul Marathon is the only marathon in the World, where the course includes two continents between Asia and Europe that takes place every year in Turkey. It attracts the attention of athletes 106 different countries from all around the World, and more than 37.000 athletes participated in the event in 2019. This article aims to determine the impact of the Istanbul Marathon has on the City of Istanbul economy.

Research Objective. To the satisfaction of participants of the Istanbul Marathon is compared with the cost items spent during the organization.

\section{METHODS}

Participants. The universe of the research is composed of 1420 non-resident and 28580 resident runners who participated in the 41 st Istanbul Marathon on 3 November 2019. The sample of this study consisted of 247 non-resident, and 1341 resident runners participated by voluntary selection method who participated in the Marathon.

Data Collection. The data collection process was carried out between 13.12.2019 - 18.12.2019 through online questionnaire forms on the internet. The participants asked several questions during or before the Marathon with demographic information in the questionnaire form (15 questions). Also, the "Likert" system with a five-point scale was used in the questions to obtain the participants' experience on Marathon. The options included in Likert-type questions indicate the level of participation in expression and statement containing attitude or opinion about the subject under investigation. For this reason, the level of participation is determined by offering multiple options between the two extremes in Likert-type questions. During the analysis, these options are coded by giving a numerical value according to their degrees. In this way, qualitative data is converted into quantitative data. (25).

Table 1. Scale of Research Questions Method

\begin{tabular}{lcccc}
\hline Minimum & Low & Medium & High & Maximum \\
\hline 1 & 2 & 3 & 4 & 5 \\
\hline
\end{tabular}

A measure of central tendency is attempted to be identified in the research questions. Therefore, there are no trap questions.

Therefore, the questionnaire is not contained trick questions.

Factor analysis was applied to the data obtained as a result of the survey form. The underlying assumption of factor analysis is that the correlation matrix between variables is different from the unit matrix. In the unit matrix, dimensions cannot be reduced, and factors cannot be obtained. In other words, there are no significant correlations between the variables of interest. Therefore, the equation of the correlation matrix to the unit matrix should be measured. The zero hypothesis is tested with Bartlett's sphericity test. Refusal of the hypothesis means that the data are suitable for factor analysis. Another statistic used to measure the suitability of the data for factor analysis is the Kaiser-Meyer-Olkin (KMO) statistic. Correlation coefficients between the variables are obtained by proportioning them to partial correlation coefficients. It is in the range of 0 and 1 . If the $\mathrm{KMO}$ value is close to 1 , it means that the data are suitable for factor analysis. The KMO value below 0.5 means that the data are not suitable for factor analysis. Therefore, Bartlett's sphericity test and the results of the KMO value should be examined first and whether the data are suitable for factor analysis should be evaluated (26). There are four primary stages in factor analysis. These stages (27):

- The stage of determining the suitability of the data set for factor analysis: The determination of the suitability o the data set for factor analysis is also carried out in 3 stages. These stages are the creation of the correlation matrix, the Bartlett test and the KaiserMeyer-Olkin (KMO) test.

- Factor acquisition phase: At the Factor Acquisition stage, it is aimed to find a small number of factors with the highest rating in representing the relationships between the variables.

- Rotation factors: In the stage of rotation of the factors, it is aimed to obtain names and interpretable factors.

- Factor naming stage: During the naming factor, the relevant information is interpreted with SPSS outputs. 
Data Analysis. In this study, factor analysis was applied to the data obtained from the questionnaire form in SPSS 20 program. In the study, the participants were asked to determine the items containing the organizational processes before the marathon and the cost items required for these processes in order of importance. Since the sentence "Please tick the most appropriate option for you" was added to the questionnaire, any participant could not mark more than one option. The first part of the analysis was made for "non-resident" participants and the second part for "resident" participants. The purpose of this analysis is to compare the satisfaction rate of the participants for the marathon in some aspects of the organization process, and the costs incurred in these processes. Thus, it is determined how the issues in organizational processes are important for the participants, and how the costs of these issues are perceived for them.

\section{RESULTS}

The satisfaction level of "non-resident participants" are measured in essential issues in the organization of the event in question 14.

KMO test and Barlett Analysis results are shown in Table 2.

Table 2. KMO and Bartlett's Test- Non-Resident

\begin{tabular}{lc}
\hline $\begin{array}{l}\text { Kaiser-Meyer-Olkin Measure Sampling } \\
\text { Adequacy. }\end{array}$ & $\mathbf{0 . 9 6 6}$ \\
\hline Bartlett's test of sphericity & \\
Approx.chi-square & 3524.140 \\
df & 136 \\
Sig. & 0.000 \\
\hline
\end{tabular}

Table 3. Reliability Analysis- Non-Resident

\begin{tabular}{lcc}
\hline $\begin{array}{l}\text { Cronbach's Alpha Based on } \\
\text { Standarized Items }\end{array}$ & $\begin{array}{c}\text { N of } \\
\text { Items }\end{array}$ & $\begin{array}{c}\text { Cronbach's } \\
\text { Alfa }\end{array}$ \\
\hline $\mathbf{0 . 9 6 4}$ & 17 & 0.963 \\
\hline
\end{tabular}

In this research, sampling adequacy is measured by KMO (Kaiser-Mayer-Olkin) test. There are sample size results with the test. The ratio is expected to be higher than 0.50 for performing factor analysis applications. The fact that the rates of Barlett analysis are close to 0 shows that the results are significant. At the same time, the statistical significance of chi-square value shows that the research data is appropriately structured (28). As can be seen in Table 2, the KMO test is measured as 0.966 and is suitable for factor analysis of the data set. Also, Bartlett analysis must be $\mathrm{P}<0.05$. This condition is also met. The data are suitable for factor analysis. As these statistical tests are suitable for factor analysis, it is understood that there are high correlations between variables. "Total Variance Explained" method is used to determine the number of factors. As can be seen in Table 3, Cronbach's Alpha value is 0,963 . This value is qualified as a highly reliable scale.

Table 4, the sample suitability criterion of all components is observed in the anti-image correlation matrices created where the acceptability limit is higher than 0.5 .

Table 5 shows how much each factor affects the total factor. Extraction values in this table are expected to be over 30. The factor "I would recommend the event to someone else" is the most influential factor in shaping the total factor with a rate of $76 \%$. The "I will definitely participate again" is the factor that has the least impact on shaping the total factor with $38 \%$.

In the cumulative (\%) column, the percentage of factors explained is given. In Table 6, the factors in the total column with an eigenvalue more significant than one are evaluated as the number of factors. It can be seen from the values given in Table 6 , where the number of factors is 1 . The contribution of one factor to variance is $63.641 \%$. Participants were asked to mark the most appropriate option for them in question 15 , which is prepared for evaluating the cost items specified in the articles in terms of necessity. The results of the KMO test and Barlett Analysis are shown in Table 7.

Table 4. Anti-Image Correlation Matrix-Non-Resident

\begin{tabular}{|c|c|c|c|c|c|c|c|c|c|c|c|c|c|c|c|c|c|}
\hline & A1 & A2 & A3 & A4 & A5 & A6 & A7 & A8 & A9 & $\mathbf{A 1 0}$ & A11 & A12 & A13 & A14 & A15 & A16 & A17 \\
\hline A1 & .968 & -.226 & .005 & -.059 & .066 & -.070 & -.023 & -.011 & .046 & -.005 & -.095 & -.096 & -.058 & .146 & .057 & -.152 & -.002 \\
\hline A2 & -.226 & .965 & -.205 & -.126 & -.224 & .123 & .069 & -.007 & .021 & -.062 & -.007 & .007 & -.130 & -.104 & -.043 & .016 & -.170 \\
\hline A3 & .005 & -.205 & .970 & -.064 & -.086 & .000 & -.073 & -.009 & -.144 & -.128 & .056 & .119 & .010 & -.114 & -.048 & .015 & -.272 \\
\hline A4 & -.059 & -.126 & -.064 & .983 & -.028 & -.174 & -.057 & -.092 & -.011 & -.069 & .011 & .076 & -.040 & -.079 & -.140 & -.051 & -.042 \\
\hline A5 & .066 & -.224 & -.086 & -.028 & .956 & -.250 & -.182 & -.113 & -.216 & .160 & -.005 & -.036 & .028 & .105 & -.102 & .068 & -.133 \\
\hline A6 & -.070 & .123 & .000 & -.174 & -.250 & .961 & -.128 & -.072 & -.025 & -.154 & -0.66 & .094 & -.218 & -.012 & -.234 & .002 & .049 \\
\hline A7 & -.023 & .069 & -.073 & -.057 & -.182 & -.128 & .973 & -.051 & -.110 & .054 & .057 & -.172 & -.004 & -.109 & .091 & .014 & -.118 \\
\hline A8 & -.011 & -.007 & -.009 & -.092 & -.113 & -.072 & -.051 & .982 & .027 & .021 & -.100 & -.036 & -.137 & -.037 & -.062 & .013 & .083 \\
\hline A9 & .046 & .021 & -.144 & -.011 & -.216 & -.025 & -.110 & .027 & .956 & -.278 & -.199 & -.104 & -.040 & 0.64 & -.055 & -.086 & .212 \\
\hline A10 & -.005 & -.062 & -.128 & -.069 & .160 & -.154 & .054 & .021 & -.278 & .957 & -.204 & -.257 & -.066 & -.044 & .106 & -.031 & -.189 \\
\hline A11 & -.095 & -.007 & .056 & .011 & -.005 & -.066 & .057 & -.100 & -.199 & -.204 & .970 & -.134 & .012 & .052 & -.056 & .125 & -.148 \\
\hline A12 & -.096 & .007 & .119 & .076 & -.036 & .094 & -.172 & -.036 & -.104 & -.257 & -.134 & .963 & -.220 & -.146 & -.151 & -.004 & -.125 \\
\hline A13 & -.058 & -.130 & .010 & -.040 & .028 & -.218 & -.004 & -.137 & -.040 & -.066 & .012 & -.220 & .976 & -.147 & -.001 & .006 & -.026 \\
\hline A14 & .146 & -.104 & -.114 & -.079 & .105 & -.012 & -.109 & -.037 & .064 & -.044 & .052 & -.146 & -.147 & .965 & -.258 & -.077 & .038 \\
\hline A15 & -.057 & -.043 & -.048 & -.140 & -.102 & -.234 & .091 & -.062 & -.055 & .106 & -.056 & -.151 & -.001 & -.258 & .969 & -.068 & -.125 \\
\hline A16 & -.152 & 0.16 & .015 & -.051 & .068 & .002 & .014 & .013 & -.086 & -.031 & .125 & -.004 & .006 & -.077 & -.068 & .961 & -.307 \\
\hline A17 & -.002 & -.170 & -.272 & -.042 & -.133 & .049 & -.118 & .083 & .212 & -.189 & -.148 & -.125 & -.026 & .038 & -.125 & -.307 & .951 \\
\hline
\end{tabular}


Table 5. Communalities- Non-Resident

\begin{tabular}{lcc}
\hline & Initial & Extraction \\
\hline I was pleased with the registration process & 1.000 & 0.447 \\
I was satisfied with the event area & 1.000 & 0.706 \\
I was satisfied with the racecourse & 1.000 & 0.692 \\
I was pleased with the refreshment stations & 1.000 & 0.670 \\
I was satisfied with the start area & 1.000 & 0.666 \\
I was satisfied with pace gate & 1.000 & 0.713 \\
I was satisfied with the luggage buses and drop bags & 1.000 & 0.568 \\
I was satisfied with toilet facilities & 1.000 & 0.427 \\
I was satisfied with transportation to the start area & 1.000 & 0.620 \\
I was satisfied with security services & 1.000 & 0.741 \\
I was satisfied with timing system & 1.000 & 0.585 \\
I was pleased with the attitude and behavior of the officials & 1.000 & 0.742 \\
I was pleased with the health services of the event & 1.000 & 0.712 \\
I was satisfied with the food packages delivered after the race & 1.000 & 0.590 \\
I was satisfied with the event operation process & 1.000 & 0.755 \\
I will definitely participate again & 1.000 & 0.424 \\
I would recommend the event to someone else & 1.000 & 0.761 \\
\hline
\end{tabular}

\begin{tabular}{lccccc}
\multicolumn{5}{c}{ Table 6. Total Variance Explained- Non-Resident } \\
\hline Component & Total & $\begin{array}{c}\text { Initial Eigenvalues } \\
(\boldsymbol{\%}) \text { of Variance }\end{array}$ & \multicolumn{3}{c}{$\begin{array}{c}\text { Cxtraction Sums of Squared Loadings } \\
\text { Cumulative }(\boldsymbol{\%})\end{array}$} \\
\hline $\mathbf{1}$ & 10.819 & 63.641 & 63.641 & 10.819 & 63.641 \\
$\mathbf{2}$ & 0.794 & 4.671 & 68.312 & & \\
$\mathbf{3}$ & 0.660 & 3.881 & 72.193 & & \\
$\mathbf{4}$ & 0.619 & 3.641 & 75.834 & & \\
$\mathbf{5}$ & 0.543 & 3.193 & 79.027 & & \\
$\mathbf{6}$ & 0.493 & 2.900 & 81.928 & & \\
$\mathbf{7}$ & 0.458 & 2.691 & 84.619 & & \\
$\mathbf{8}$ & 0.407 & 2.393 & 87.012 & & \\
$\mathbf{9}$ & 0.342 & 2.10 & 89.022 & & \\
$\mathbf{1 0}$ & 0.330 & 1.943 & 90.965 & & \\
$\mathbf{1 1}$ & 0.313 & 1.840 & 92.805 & & \\
$\mathbf{1 2}$ & 0.270 & 1.589 & 94.393 & & \\
$\mathbf{1 3}$ & 0.243 & 1.431 & 95.824 & & \\
$\mathbf{1 4}$ & 0.213 & 1.253 & 97.077 & & \\
$\mathbf{1 5}$ & 0.194 & 1.143 & 98.219 & & \\
$\mathbf{1 6}$ & 0.161 & 0.946 & 99.166 & & \\
$\mathbf{1 7}$ & 0.142 & 0.834 & 100.000 & & \\
\hline
\end{tabular}

Extraction method: principal component analysis.

Table 7. KMO and Bartlett's Test- Non-Resident

\begin{tabular}{lc}
\hline Kaiser-Meyer-Olkin Measure Sampling & 0.915 \\
Adequacy & \\
\hline Bartlett's test of sphericity & 3032.910 \\
Approx.chi-square & 105 \\
df & 0.000 \\
Sig.
\end{tabular}

Table 8. Reliability Analysis- Non-Resident

\begin{tabular}{lcc}
\hline $\begin{array}{l}\text { Cronbach Alpha Based on } \\
\text { Standardized Items }\end{array}$ & $\begin{array}{c}\text { No of } \\
\text { items }\end{array}$ & $\begin{array}{c}\text { Cronbach's } \\
\text { Alfa }\end{array}$ \\
\hline $\mathbf{0 . 9 4 1}$ & 16 & 0.940 \\
\hline
\end{tabular}

As can be seen in Table 7, the KMO test increased to 0.915 . This result is a good result for analysis. The data set of $0.915>0.50$ appears to be suitable for factor analysis. Also, Barlett analysis must be $\mathrm{P}<0.50$. This condition is also met. The data are suitable for factor analysis. "Total Variance Explained" method is used to determine the number of factors. Cronbach's Alpha value has increased to 0.940 in Table 8 . This value is qualified as a highly reliable scale.

Table 9, it is observed in the anti-image correlation matrices that the sample suitability criterion of all components is higher than the acceptable limit of 0.5 .

Table 9. Anti-Image Correlation Matrix- Non-Resident

\begin{tabular}{lccccccccccccccccc}
\hline & B1 & B2 & B3 & B4 & B5 & B6 & B7 & B8 & B9 & B10 & B11 & B12 & B13 & B14 & B15 \\
\hline B1 & .880 & -0.461 & -0.032 & 0.035 & -0.002 & -0.120 & 0.033 & -0.106 & 0.132 & 0.071 & -0.076 & -0.032 & 0.141 & -0.141 & -0.012 \\
B2 & -0.461 & 0.888 & -0.123 & -0.063 & 0.072 & -0.069 & -0.072 & 0.209 & -0.311 & -0.053 & -0.152 & -0.149 & 0.044 & -0.025 & 0.027 \\
B3 & -0.032 & -0.123 & 0.917 & -0.547 & -0.227 & 0.003 & -0.037 & -0.082 & 0.051 & -0.001 & 0.180 & -0.094 & -0.126 & 0.021 & -0.038 \\
B4 & 0.035 & -0.063 & -0.547 & 0.898 & 0.015 & -0.070 & 0.119 & -0.417 & 0.095 & -0.066 & -0.052 & 0.018 & -0.081 & 0.072 & -0.056 \\
B5 & -0.002 & 0.072 & -0.227 & 0.015 & 0.932 & -0.440 & -0.060 & -0.057 & -0.123 & -0.001 & -0.076 & 0.127 & -0.005 & -0.067 & -0.070 \\
B6 & -0.120 & -0.069 & 0.003 & -0.070 & -0.440 & 0.938 & -0.159 & -0.024 & -0.092 & 0.000 & -0.032 & 0.038 & -0.060 & 0.070 & 0.030 \\
B7 & 0.033 & -0.072 & -0.037 & 0.119 & -0.060 & -0.159 & 0.947 & -0.409 & -0.047 & 0.009 & 0.049 & -0.156 & -0.081 & -0.035 & -0.037 \\
B8 & -0.106 & 0.209 & -0.082 & -0.417 & -0.057 & -0.024 & -0.409 & 0.912 & -0.134 & -0.178 & -0.008 & 0.051 & 0.080 & -0.074 & -0.016 \\
B9 & 0.132 & -0.311 & 0.051 & 0.095 & -0.123 & -0.092 & -0.047 & -0.134 & 0.919 & 0.113 & 0.025 & -0.324 & -0.060 & -0.050 & -0.040 \\
B10 & 0.071 & -0.053 & -0.001 & -0.066 & -0.001 & 0.000 & 0.009 & -0.178 & 0.113 & 0.880 & -0.087 & 0.101 & -0.094 & -0.095 & -0.672 \\
B11 & -0.076 & -0.152 & 0.180 & -0.052 & -0.076 & -0.032 & 0.049 & -0.008 & 0.025 & -0.087 & 0.917 & -0.476 & -0.128 & -0.017 & -0.053 \\
B12 & -0.032 & -0.149 & -0.094 & 0.018 & 0.127 & 0.038 & -0.156 & 0.051 & -0.324 & 0.101 & -0.476 & 0.893 & -0.152 & -0.157 & -0.006 \\
B13 & 0.141 & 0.044 & -0.126 & -0.081 & -0.005 & -0.060 & -0.081 & 0.080 & -0.060 & -0.094 & -0.128 & -0.152 & 0.947 & -0.340 & 0.039 \\
B14 & -0.141 & -0.025 & 0.021 & 0.072 & -0.067 & 0.070 & -0.035 & -0.074 & -0.050 & -0.095 & -0.017 & -0.157 & -0.340 & 0.951 & -0.040
\end{tabular}


\begin{tabular}{lllllllllllllllll} 
B15 & -0.012 & 0.027 & -0.038 & -0.056 & -0.070 & 0.030 & -0.037 & -0.016 & -0.040 & -0.672 & -0.053 & -0.006 & 0.039 & -0.040 & 0.894 \\
\hline
\end{tabular}

Table 10. Communalities- Non-Resident

\begin{tabular}{lcc}
\hline & Initial & Extraction \\
\hline Prize purse is required & 1.000 & 0.468 \\
Live broadcast service is required & 1.000 & 0.735 \\
Bib number is required & 1.000 & 0.772 \\
Timing system is required & 1.000 & 0.803 \\
Race t-shirts are required & 1.000 & 0.649 \\
Race bags are required & 1.000 & 0.583 \\
EXPO organization are required & 1.000 & 0.658 \\
Start and finish organizations are required & 1.000 & 0.817 \\
Posters. vinyl and other promotional materials are required & 10.000 & .664 \\
Transportation service required on race morning & 10.000 & .723 \\
Age groups award ceremony is required & 10.000 & .691 \\
Press conference organizations are required0. & 1.000 & 0.804 \\
Barriers are required in the event areas and the course & 1.000 & 0.594 \\
Sponsorship activities are required & 1.000 & 0.589 \\
Free transportation to the start area is required & 1.000 & 0.694 \\
\hline
\end{tabular}

Table 11. Total Variance Explained- Non-Resident

\begin{tabular}{|c|c|c|c|c|c|c|}
\hline \multirow[t]{2}{*}{ Component } & \multicolumn{3}{|c|}{ Initial Eigenvalues } & \multicolumn{3}{|c|}{ Extraction Sums of Squared Loadings } \\
\hline & Total & $(\%)$ of Variance & Cumulative (\%) & Total & $(\%)$ of Variance & Cumulative (\%) \\
\hline 1 & 8.267 & 55.115 & 55.115 & 8.267 & 55.115 & 55.115 \\
\hline 2 & 1.979 & 13.190 & 68.306 & 1.979 & 13.190 & 68.306 \\
\hline 3 & 0.869 & 5.794 & 74.100 & & & \\
\hline 4 & 0.718 & 4.786 & 78.886 & & & \\
\hline 5 & 0.499 & 3.324 & 82.210 & & & \\
\hline 6 & 0.476 & 3.172 & 85.382 & & & \\
\hline 7 & 0.428 & 2.850 & 88.232 & & & \\
\hline 8 & 0.381 & 2.538 & 90.771 & & & \\
\hline 9 & 0.300 & 2.001 & 92.772 & & & \\
\hline 10 & 0.252 & 1.677 & 94.449 & & & \\
\hline 11 & 0.243 & 1.617 & 96.066 & & & \\
\hline 12 & 0.199 & 1.329 & 97.395 & & & \\
\hline 13 & 0.148 & 0.987 & 98.381 & & & \\
\hline 14 & 0.133 & 0.888 & 99.269 & & & \\
\hline 15 & 0.110 & 0.731 & 100.000 & & & \\
\hline
\end{tabular}

Extraction method: principal component analysis.

Table 10 shows how much each factor affects the total factor. Extraction values in this table are expected to be over 0.30 . The "Start and finish organizations are required" is the factor that is the most impact on shaping the total factor with a rate of $81 \%$. "The Prize purse is required" is the factor that has the least impact on shaping the total factor with its $46 \%$ ratio.
The cumulative (\%) column gives the percentage of factors explained. In Table 11, there are factors in the total column with an eigenvalue greater than 1 . It is seen that the number of factors is 2 in the values given in Table 11. The contribution of 2 factors to variance is $68,306 \%$. It also has a two-dimensional structure.

Table 12. Rotated Component Matrix- Non-Resident

\begin{tabular}{lcc}
\hline & \multicolumn{2}{c}{ Factors } \\
& $\mathbf{1}$ & $\mathbf{2}$ \\
\hline Start and finish organizations are required & 0.819 & -0.382 \\
Bib number is required & 0.815 & -0.329 \\
EXPO organization is required & 0.808 & \\
Timing System is required & 0.799 & -0.405 \\
Race t-shirts are required & 0.768 & -0.245 \\
Barriers are required in the event areas and the course & 0.765 & \\
Race bags are required & 0.760 & \\
Transportation service required on race morning & 0.742 & -0.379 \\
Sponsorship activities are required & 0.740 & 0.205 \\
Free transportation to the start area is required & 0.736 & -0.426 \\
Press conference organizations are required. & 0.717 & 0.538 \\
Age groups award ceremony is required & 0.703 & 0.443 \\
Live broadcast service is required & 0.682 & 0.520 \\
Posters. vinyl and other promotional materials are required & 0.680 & 0.450 \\
Prize purse is required & 0.561 & 0.392 \\
\hline Extraction method: primcipal compont andysis.
\end{tabular}

Extraction method: principal component analysis. A.2 components extracted. 
Table 13. Marathon Process- Non-Resident

\begin{tabular}{lcc}
\hline F01 & I would like to recommend the event to someone else & $(0.761)$ \\
F02 & I was satisfied with the event operation process & $(0.755)$ \\
F03 & I was pleased with the attitude and behaviour of the officials & $(0.742)$ \\
F04 & I was satisfied with security services & $(0.741)$ \\
F05 & I was satisfied with pace gate & $(0.713)$ \\
F06 & I was pleased with the health services of the event & $(0.712)$ \\
F07 & I was satisfied with the event area & $(0.706)$ \\
F08 & I was satisfied with the racecourse & $(0.692)$ \\
F09 & I was pleased with the refreshment stations & $(0.670)$ \\
F010 & I was satisfied with the start area & $(0.666)$ \\
F011 & I was satisfied with transportation to the start area & $(0.620)$ \\
F012 & I was satisfied with the food packages delivered after the race & $(0.590)$ \\
F013 & I was satisfied with timing system & $(0.585)$ \\
F014 & I was satisfied with the luggage buses and drop bags & $(0.568)$ \\
F015 & I was pleased with the registration process & $(0.447)$ \\
F016 & I was satisfied with toilet facilities & $(0.427)$ \\
F017 & I will definitely participate again & $(0.424)$ \\
\hline
\end{tabular}

KMO = 0.966, Chi-square $=3524.140 . P=0.000$, Cronbach's Alpha $=0.963$, Total variance explanation rate $=63.641 \%$

Table 14. Costs in the Marathon Process- Non-Resident

\begin{tabular}{lcc}
\hline F01 & Start and finish organizations are required & $(0.817)$ \\
F02 & Press conference organizations are required & $(0.804)$ \\
F03 & Timing System is required & $(0.803)$ \\
F04 & Bib number is required & $(0.772)$ \\
F05 & Live broadcast service is required & $(0.735)$ \\
F06 & Transportation service required on race morning & $(0.723)$ \\
F07 & Free transportation to the start area is required & $(0.694)$ \\
F08 & Age groups award ceremony is required & $(0.691)$ \\
F09 & Posters. vinyl and other promotional materials are required & $(0.664)$ \\
F010 & EXPO organization is required & $(0.658)$ \\
F011 & Race t-shirts are required & $(0.649)$ \\
F012 & Barriers are required in the event areas and the course & $(0.594)$ \\
F013 & Sponsorship activities are required & $(0.589)$ \\
F014 & Race bags are required & $(0.583)$ \\
F015 & Prize purse is required & $(0.468)$ \\
\hline
\end{tabular}

KMO $=0.915$, Chi-square $=3261.119 \mathrm{P}=0.000$, Cronbach's Alpha $=, 940$, Total variance disclosure rate $=68,306 \%$

Table 15. KMO and Bartlett's Test- Resident

\begin{tabular}{lc}
\hline $\begin{array}{l}\text { Kaiser-Meyer-Olkin Measure Sampling } \\
\text { Adequacy. }\end{array}$ & $\mathbf{0 . 9 7 4}$ \\
\hline Bartlett's test of sphericity & \\
Approx.chi-square & 28768.224 \\
df & 136 \\
Sig. & 0.000 \\
\hline
\end{tabular}

Table 16. Reliability Analysis- Resident

\begin{tabular}{lcc}
\hline $\begin{array}{l}\text { Cronbach's Alpha Based on } \\
\text { Standarized Items }\end{array}$ & $\begin{array}{c}\text { No of } \\
\text { Items }\end{array}$ & $\begin{array}{c}\text { Cronbach's } \\
\text { Alfa }\end{array}$ \\
\hline $\mathbf{0 . 9 6 4}$ & 17 & 0.978 \\
\hline
\end{tabular}

Two factors (columns) and weights of each variable under factors (factor loadings - correlation coefficient between variables and factors) are given in Table 12. In this table, the "Start and finish organizations are required" variable has taken the highest weight under the first factor 0 819) in the line, the "Bib number is required" variable (0 815) and "EXPO organization is required" variable (0 808). It has the highest weight under the 1st factor, while "Press conference organizations required variable" had the highest weights under the 2 nd factor (0.538).
The sample created to determine the contribution of major sports events to the city economy is interpreted as follows as a result of the factor analysis applied.

The satisfaction level of "resident participants" are measured in important issues in the organization of the event in question 14. KMO test and Barlett Analysis results are shown in Table 13.

The KMO test is 0.974 in Table 15 . This result is a good result for analysis. It is seen that the data set is suitable for factor analysis because KMO is $0.974>$ 0.60 . Barlett analysis must also be $\mathrm{P}<0.05$. The data are suitable for factor analysis. As these statistical tests are suitable for factor analysis, it is understood that there are high correlations between variables. "Total Variance Explained" method is determinate the number of factors.

As can be seen in Table 16, Cronbach's Alpha value has increased to 0.978 . This value is qualified as a highly reliable scale.

As can be seen in Table 15, it is observed in the anti-image correlation matrices that the sample 
suitability criterion of all components is higher than the acceptable limit of 0.5 .

Table 16 shows how much each factor affects the total factor. Extraction values in this table are expected to be over 30. The factor "I was satisfied with the event operation process" is the most influential in shaping the total factor with a rate of $86 \%$. The "I was satisfied with toilet facilities" is the factor that has the least impact on shaping the total factor with $44 \%$.

The cumulative (\%) column gives the percentage of factors explained. In Table 17, there are factors in the total column with an eigenvalue greater than 1 . It is seen that the number of factors is 1 in the values given in Table 17.

\begin{tabular}{|c|c|c|c|c|c|c|c|c|c|c|c|c|c|c|c|c|c|}
\hline & A1 & A2 & A3 & A4 & A5 & A6 & A7 & A8 & A9 & A10 & A11 & $\mathbf{A 1 2}$ & A13 & A14 & A15 & A16 & A17 \\
\hline A1 & 0.985 & -0.213 & -0.020 & -0.088 & 0.039 & 0.028 & -0.095 & -0.009 & 0.020 & -0.042 & -0.156 & -0.019 & -0.016 & 0.053 & -0.149 & -0.077 & 0.038 \\
\hline A2 & -0.213 & 0.982 & -0.179 & -0.027 & -0.188 & -0.017 & -0.010 & -0.024 & -0.060 & -0.060 & 0.021 & 0.039 & -0.039 & -0.033 & -0.138 & 0.033 & $\begin{array}{c}- \\
0.120\end{array}$ \\
\hline A3 & -0.020 & -0.179 & 0.990 & -0.061 & -0.021 & -0.085 & -0.044 & 0.019 & -0.011 & -0.075 & -0.028 & -0.076 & -0.011 & 0.027 & 0.035 & 0.012 & $\begin{array}{c}- \\
0.163\end{array}$ \\
\hline A4 & -0.088 & -0.027 & -0.061 & 0.984 & -0.141 & -0.145 & -0.019 & -0.071 & -0.004 & -0.050 & 0.022 & -0.029 & -0.080 & -0.253 & -0.050 & -0.014 & 0.034 \\
\hline A5 & 0.039 & -0.188 & -0.021 & -0.141 & 0.966 & -0.368 & -0.095 & -0.046 & -0.094 & -0.003 & -0.011 & 0.103 & 0.001 & 0.100 & -0.115 & 0.008 & $\begin{array}{c}- \\
0.003\end{array}$ \\
\hline A6 & 0.028 & -0.017 & -0.085 & -0.145 & -0.368 & 0.975 & -0.144 & -0.058 & -0.008 & -0.052 & 0.012 & -0.095 & 0.013 & 0.012 & -0.062 & 0.009 & $\begin{array}{c}- \\
0.001\end{array}$ \\
\hline A7 & -0.095 & -0.010 & -0.044 & -0.019 & -0.095 & -0.144 & 0.984 & -0.164 & -0.164 & 0.008 & -0.151 & -0.057 & -0.091 & -0.068 & 0.056 & -0.001 & $\begin{array}{c}- \\
0.018\end{array}$ \\
\hline A8 & -0.009 & -0.024 & 0.019 & -0.071 & -0.046 & -0.058 & -0.164 & 0.986 & -0.106 & -0.007 & -0.002 & 0.012 & -0.083 & -0.108 & 0.036 & 0.030 & $\begin{array}{c}- \\
0.002\end{array}$ \\
\hline A9 & 0.020 & -0.060 & -0.011 & -0.004 & -0.094 & -0.008 & -0.164 & -0.106 & 0.980 & -0.255 & 0.065 & 0.043 & 0.012 & -0.055 & -0.087 & -0.061 & 0.048 \\
\hline A10 & -0.042 & -0.060 & -0.075 & -0.050 & -0.003 & -0.052 & 0.008 & -0.007 & -0.255 & 0.981 & -0.168 & -0.217 & -0.138 & 0.043 & -0.044 & -0.056 & 0.040 \\
\hline A11 & -0.156 & 0.021 & -0.028 & 0.022 & -0.011 & 0.012 & -0.151 & -0.002 & 0.065 & -0.168 & 0.978 & -0.333 & -0.100 & -0.006 & -0.044 & -0.052 & $\begin{array}{c}- \\
0.016\end{array}$ \\
\hline A12 & -0.019 & 0.039 & -0.076 & -0.029 & 0.103 & -0.095 & -0.057 & 0.012 & 0.043 & -0.217 & -0.333 & 0.971 & -0.273 & 0.016 & -0.152 & -0.021 & $\begin{array}{c}- \\
0.049\end{array}$ \\
\hline A13 & -0.016 & -0.039 & -0.011 & -0.080 & 0.001 & 0.013 & -0.091 & -0.083 & 0.012 & -0.138 & -0.100 & -0.273 & 0.986 & -0.057 & -0.071 & -0.019 & $\begin{array}{c}- \\
0.035\end{array}$ \\
\hline A14 & 0.053 & -0.033 & 0.027 & -0.253 & 0.100 & 0.012 & -0.068 & -0.108 & -0.055 & 0.043 & -0.006 & 0.016 & -0.057 & 0.974 & -0.309 & -0.049 & 0.001 \\
\hline A15 & -0.149 & -0.138 & 0.035 & -0.050 & -0.115 & -0.062 & 0.056 & 0.036 & -0.087 & -0.044 & -0.044 & -0.152 & -0.071 & -0.309 & 0.978 & -0.021 & $\begin{array}{c}- \\
0.143\end{array}$ \\
\hline A16 & -0.077 & 0.033 & 0.012 & -0.014 & 0.008 & 0.009 & -0.001 & 0.030 & -0.061 & -0.056 & -0.052 & -0.021 & -0.019 & -0.049 & -0.021 & 0.936 & $\begin{array}{c}- \\
0.794\end{array}$ \\
\hline A17 & 0.038 & -0.120 & -0.163 & 0.034 & -0.003 & -0.001 & -0.018 & -0.002 & 0.048 & 0.040 & -0.016 & -0.049 & -0.035 & 0.001 & -0.143 & -0.794 & 0.932 \\
\hline
\end{tabular}

Table 18. Communalities - Resident

\begin{tabular}{lcc}
\hline & Initial & Extraction \\
\hline I was pleased with the registration process & 1.000 & 0.728 \\
I was satisfied with the event area & 1.000 & 0.787 \\
I was satisfied with the racecourse & 1.000 & 0.728 \\
I was pleased with the refreshment stations & 1.000 & 0.721 \\
I was satisfied with the start area & 1.000 & 0.628 \\
I was satisfied with pace gate & 1.000 & 0.713 \\
I was satisfied with the luggage buses and drop bags. & 1.000 & 0.756 \\
I was satisfied with toilet facilities & 1.000 & 0.442 \\
I was satisfied with transportation to the start area & 1.000 & 0.616 \\
I was satisfied with security services & 1.000 & 0.820 \\
I was satisfied with timing system & 1.000 & 0.815 \\
I was pleased with the attitude and behavior of the officials & 1.000 & 0.848 \\
I was pleased with the health services of the event & 1.000 & 0.822 \\
I was satisfied with the food packages delivered after the race & 1.000 & 0.666 \\
I was satisfied with the event operation process & 1.000 & 0.869 \\
I will definitely participate again & 1.000 & 0.829 \\
I would recommend the event to someone else & 1.000 & 0.838 \\
\hline
\end{tabular}

Extraction method: principal component analysis.

Table 19. Total Variance Explained - Resident

\begin{tabular}{|c|c|c|c|c|c|c|}
\hline \multirow[t]{2}{*}{ Component } & \multicolumn{3}{|c|}{ Initial Eigenvalues } & \multicolumn{3}{|c|}{ Extraction Sums of Squared Loadings } \\
\hline & Total & (\%) of Variance & Cumulative (\%) & Total & (\%) of Variance & Cumulative $(\%)$ \\
\hline 1 & 12.625 & 74.264 & 74.264 & 12.625 & 74.264 & 74.264 \\
\hline 2 & 0.696 & 4.095 & 78.358 & & & \\
\hline 3 & 0.525 & 3.088 & 81.446 & & & \\
\hline 4 & 0.419 & 2.467 & 83.912 & & & \\
\hline 5 & 0.405 & 2.385 & 86.297 & & & \\
\hline 6 & 0.346 & 2.035 & 88.332 & & & \\
\hline 7 & 0.306 & 1.800 & 90.132 & & & \\
\hline 8 & 0.270 & 1.589 & 91.721 & & & \\
\hline 9 & 0.249 & 1.467 & 93.187 & & & \\
\hline 10 & 0.222 & 1.304 & 94.492 & & & \\
\hline 11 & 0.210 & 1.236 & 95.728 & & & \\
\hline 12 & 0.181 & 1.066 & 96.794 & & & \\
\hline 13 & 0.154 & 0.909 & 97.702 & & & \\
\hline 14 & 0.140 & 0.822 & 98.524 & & & \\
\hline 15 & 0.118 & 0.696 & 99.220 & & & \\
\hline
\end{tabular}




\begin{tabular}{lllc}
$\mathbf{1 6}$ & 0.096 & 0.562 & 99.781 \\
$\mathbf{1 7}$ & 0.037 & 0.219 & 100.000 \\
\hline
\end{tabular}

Extraction method: principal component analysis.

Table 20. KMO and Bartlett's Test- Resident

\begin{tabular}{lc}
\hline Kaiser-Meyer-Olkin Measure Sampling Adequacy & 0.976 \\
\hline Bartlett's test of sphericity & \\
Approx. chi-square & 31061.494 \\
df & 105 \\
Sig. & 0.000 \\
\hline
\end{tabular}

Table 21. Reliability Analysis

\begin{tabular}{l|l|c}
\hline Cronbach Alpha Based on Standardized Items & No of items & Cronbach's Alfa \\
\hline
\end{tabular}
0.983

Table 22. Anti-Image Correlation Matrix- Resident

\begin{tabular}{ccccccccccccccccc}
\hline & B1 & B2 & B3 & B4 & B5 & B6 & B7 & B8 & B9 & B10 & B11 & B12 & B13 & B14 & B15 \\
\hline B1 & 0.973 & -0.326 & -0.027 & 0.020 & 0.033 & 0.001 & -0.022 & -0.012 & 0.007 & -0.050 & -0.162 & -0.026 & 0.004 & 0.079 & -0.012 \\
B2 & -0.326 & 0.975 & -0.177 & -0.125 & -0.113 & -0.009 & -0.071 & 0.035 & -0.007 & 0.080 & 0.000 & -0.185 & -0.058 & -0.019 & -0.038 \\
B3 & -0.027 & -0.177 & 0.976 & -0.430 & -0.028 & -0.051 & -0.002 & -0.079 & 0.007 & 0.002 & -0.010 & -0.008 & -0.017 & 0.018 & -0.059 \\
B4 & 0.020 & -0.125 & -0.430 & 0.969 & -0.092 & 0.041 & -0.027 & -0.151 & 0.020 & -0.131 & 0.035 & 0.031 & -0.039 & -0.228 & -0.134 \\
B5 & 0.033 & -0.113 & -0.028 & -0.092 & 0.973 & -0.414 & -0.099 & -0.137 & -0.078 & -0.014 & 0.011 & 0.100 & 0.003 & -0.125 & -0.040 \\
B6 & 0.001 & -0.009 & -0.051 & 0.041 & -0.414 & 0.975 & -0.136 & -0.010 & -0.046 & -0.036 & -0.052 & -0.052 & 0.024 & 0.036 & -0.053 \\
B7 & -0.022 & -0.071 & -0.002 & -0.027 & -0.099 & -0.136 & 0.982 & -0.268 & -0.191 & 0.068 & -0.048 & -0.108 & 0.024 & -0.032 & 0.016 \\
B8 & -0.012 & 0.035 & -0.079 & -0.151 & -0.137 & -0.010 & -0.268 & 0.982 & -0.177 & -0.126 & -0.048 & 0.044 & -0.073 & -0.088 & -0.028 \\
B9 & 0.007 & -0.007 & 0.007 & 0.020 & -0.078 & -0.046 & -0.191 & -0.177 & 0.983 & -0.060 & -0.051 & -0.255 & -0.014 & 0.003 & 0.027 \\
B10 & -0.050 & 0.080 & 0.002 & -0.131 & -0.014 & -0.036 & 0.068 & -0.126 & -0.060 & 0.963 & -0.106 & 0.027 & -0.127 & -0.126 & -0.537 \\
B11 & -0.162 & 0.000 & -0.010 & 0.035 & 0.011 & -0.052 & -0.048 & -0.048 & -0.051 & -0.106 & 0.980 & -0.324 & -0.142 & -0.097 & -0.010 \\
B12 & -0.026 & -0.185 & -0.008 & 0.031 & 0.100 & -0.052 & -0.108 & 0.044 & -0.255 & 0.027 & -0.324 & 0.969 & -0.118 & -0.114 & 0.033 \\
B13 & 0.004 & -0.058 & -0.017 & -0.039 & 0.003 & 0.024 & 0.024 & -0.073 & -0.014 & -0.127 & -0.142 & -0.118 & 0.988 & -0.211 & -0.047 \\
B14 & 0.079 & -0.019 & 0.018 & -0.228 & -0.125 & 0.036 & -0.032 & -0.088 & 0.003 & -0.126 & -0.097 & -0.114 & -0.211 & 0.981 & -0.164 \\
B15 & -0.012 & -0.038 & -0.059 & -0.134 & -0.040 & -0.053 & 0.016 & -0.028 & 0.027 & -0.537 & -0.010 & 0.033 & -0.047 & -0.164 & 0.966 \\
\hline
\end{tabular}

Table 23. Communalities - Resident

\begin{tabular}{lcc}
\hline & Initial & Extraction \\
\hline Prize purse is required & 1.000 & 0.489 \\
Live broadcast service is required & 1.000 & 0.791 \\
Bib number is required & 1.000 & 0.848 \\
Timing system is required & 1.000 & 0.906 \\
Race t-shirts are required & 1.000 & 0.845 \\
Race bags are required & 1.000 & 0.745 \\
EXPO organization are required & 1.000 & 0.792 \\
Start and finish organizations are required & 1.000 & 0.894 \\
Posters. vinyl and other promotional materials are required & 1.000 & 0.770 \\
Transportation service required on race morning & 1.000 & 0.893 \\
Age groups award ceremony is required & 1.000 & 0.817 \\
Press conference organizations are required. & 1.000 & 0.752 \\
Barriers are required in the event areas and the course & 1.000 & 0.837 \\
Sponsorship activities are required & 1.000 & 0.903 \\
Free transportation to the start area is required & 1.000 & 0.888 \\
\hline
\end{tabular}

Table 24. Total Variance Explained- Resident

\begin{tabular}{|c|c|c|c|c|c|c|}
\hline \multirow[t]{2}{*}{ Component } & \multicolumn{3}{|c|}{ Initial Eigenvalues } & \multicolumn{3}{|c|}{ Extraction Sums of Squared Loadings } \\
\hline & Total & $(\%)$ of Variance & Cumulative (\%) & Total & $(\%)$ of Variance & Cumulative $(\%)$ \\
\hline 1 & 12.168 & 81.123 & 81.123 & 12.168 & 81.123 & 81.123 \\
\hline 2 & 0.592 & 3.947 & 85.069 & & & \\
\hline 3 & 0.399 & 2.661 & 87.730 & & & \\
\hline 4 & 0.356 & 2.370 & 90.100 & & & \\
\hline 5 & 0.241 & 1.607 & 91.707 & & & \\
\hline 6 & 0.233 & 1.551 & 93.258 & & & \\
\hline 7 & 0.183 & 1.222 & 94.480 & & & \\
\hline 8 & 0.154 & 1.027 & 95.507 & & & \\
\hline 9 & 0.141 & 0.941 & 96.447 & & & \\
\hline 10 & 0.132 & 0.879 & 97.326 & & & \\
\hline 11 & 0.120 & 0.801 & 98.127 & & & \\
\hline 12 & 0.093 & 0.618 & 98.745 & & & \\
\hline 13 & 0.081 & 0.541 & 99.286 & & & \\
\hline 14 & 0.058 & 0.387 & 99.673 & & & \\
\hline 15 & 0.049 & 0.327 & 100.000 & & & \\
\hline
\end{tabular}

Extraction method: principal component analysis. 
The contribution of 1 factor to variance is $\% 74,264$. Participants were asked to mark the most appropriate option for them in question 15, which is prepared for evaluating the cost items specified in the articles in terms of necessity. The results of the KMO test and Barlett Analysis are shown in Table 17.

As can be seen in Table 20, the KMO test increased to 0.976 . This result is a good result for analysis. The data set of $0.976>0.50$ appears to be suitable for factor analysis. Also, Barlett analysis must be $\mathrm{P}<0.50$. This condition is also met. The data are suitable for factor analysis. "Total Variance Explained" method is used to determine the number of factors. As can be seen in Table 21, Cronbach's Alpha value has increased to 0.983 . This value is qualified as a highly reliable scale.

As can be seen in Table 20, it is observed that the sample suitability criterion of all components is higher than the acceptable limit of 0.5 in the anti-image correlation matrices created for the 15 th question.
Table 21 shows how much each factor affects the total factor. Extraction values in this table are expected to be over 0.30 . The "Timing System is required" is the factor that is the most impact on shaping the total factor with a rate of $90 \%$. "The Prize purse is required" is the factor that has the least impact on shaping the total factor with its $48 \%$ ratio.

The cumulative $(\%)$ column gives the percentage of factors explained. In Table 22, there are factors in the total column with an eigenvalue greater than 1 . It is seen that the number of factors is given in Table 17. The contribution of 1 factor to variance is $\% 81,123$. The sample created to determine the contribution of major sports events to the city economy is interpreted as follows as a result of the factor analysis applied.

Table 25. Marathon Process- Resident

\begin{tabular}{lcc}
\hline F01 & I was satisfied with the event operation process & $(0.869)$ \\
F02 & I was pleased with the attitude and behaviour of the officials & $(0.848)$ \\
F03 & I would like to recommend the event to someone else & $(0.838)$ \\
F04 & I will definitely participate again & $(0.829)$ \\
F05 & I was pleased with the health services of the event & $(0.822)$ \\
F06 & I was satisfied with security services & $(0.820)$ \\
F07 & I was satisfied with timing system & $(0.815)$ \\
F08 & I was satisfied with the event area & $(0.787)$ \\
F09 & I was satisfied with the luggage buses and drop bags & $(0.756)$ \\
F010 & I was pleased with the registration process & $(0.728)$ \\
F011 & I was satisfied with the racecourse & $(0.728)$ \\
F012 & I was satisfied with the food packages delivered after the race & $(0.721)$ \\
F013 & I was satisfied with pace gate & $(0.713)$ \\
F014 & I was satisfied with the food packages delivered after the race & $(0.666)$ \\
F015 & I was satisfied with the start area & $(0.628)$ \\
F016 & I was satisfied with transportation to the start area & $(00.616)$ \\
F017 & I was satisfied with toilet facilities & $(00.442)$ \\
\hline
\end{tabular}

KMO $=0.974$, Chi-square $=28768.2224 \mathrm{P}=0.000$, Cronbach's Alpha $=0$ 978, Total variance explanation rate $=74.264 \%$

Table 26. Costs in the Marathon Process- Resident

\begin{tabular}{lrr}
\hline F01 & Timing system is required & $(0.906)$ \\
F02 & Sponsorship activities are required & $(0.903)$ \\
F03 & Start and finish organizations are required & $(0.894)$ \\
F04 & Transportation service required on race morning & $(0.893)$ \\
F05 & Free transportation to the start area is required & $(0.888)$ \\
F06 & Bib number is required & $(0.848)$ \\
F07 & Race t-shirts are required & $(0.845)$ \\
F08 & Barriers are required in the event areas and the course & $(0.837)$ \\
F09 & Age groups award ceremony is required & $(0.817)$ \\
F010 & EXPO organization is required & $(0.792)$ \\
F011 & Live broadcast service is required & $(0.791)$ \\
F012 & Posters. vinyl and other promotional materials are required & $(0.770)$ \\
F013 & Press conference organizations are required & $(0.752)$ \\
F014 & Race bags are required & $(0.745)$ \\
F015 & Prize purse is required & $(0.489)$ \\
\hline
\end{tabular}

KMO $=0.973$, Chi-square $=31061,494 \mathrm{P}=\mathbf{0 . 0 0 0}$, Cronbach's Alpha $=0.983$, Total variance disclosure rate $=81,123 \%$

The relationship between the variables is examined, and a process for finding factors is performed in the exploratory factor analysis in Tables 27 and 28. The predetermined model or hypothesis regarding the relationship between variables is tested $n$ confirmatory factor analysis (27).
Confirmatory factor analysis is used in scale development and validity analysis. The analyses is aimed to verify a structure that has been previously determined or constructed (28).

The table shows the level 1 confirmatory factor analysis for the model. Fit indices related to the model were examined to ensure an acceptable fit in the model. 
As a result of the analysis, the fit values of the model is presented in the table below.

Table 27. Values of the Measurement Model-Non-Resident

\begin{tabular}{|c|c|c|}
\hline Model Fit Index & $\begin{array}{c}\text { Model } \\
\text { Suitability } \\
\text { Value }\end{array}$ & $\begin{array}{l}\text { Measured } \\
\text { Value }\end{array}$ \\
\hline$x^{2} /$ d.f. & $\leq 5.00$ & 3.736 \\
\hline GFI (Goodness of Fit Index) & $\geq 0.90$ & 0.635 \\
\hline $\begin{array}{l}\text { AGFI (Adjusted Goodness of Fit } \\
\text { Index) }\end{array}$ & $\geq 0.80$ & 0.584 \\
\hline NFI (Normed Fit Index) & $\leq 0.90$ & 0.762 \\
\hline RFI (Relative Fit Index) & $\geq 0.90$ & 0.745 \\
\hline CFI (Comparative Fit Index) & $\geq 0.90$ & 0.813 \\
\hline $\begin{array}{l}\text { RMR (Root Mean Square } \\
\text { Residual) }\end{array}$ & $0-1$ & 0.066 \\
\hline $\begin{array}{l}\text { RMSEA (Root Mean Square } \\
\text { Error of Approximation) }\end{array}$ & $0.05-0.08$ & 0.106 \\
\hline
\end{tabular}

The fit index value is obtained by dividing the chisquare value by the degree of freedom. If this ratio is equal to a value of three or less than three, the model is a good model; equal to a value of five or less indicates that the model has an acceptable goodness of fit. In the model discussed in the study, the mentioned value is 3.736 and it is below the value of 5 .

GFI, RFI, CFI, RMSEA values are not granted proper for the model. Therefore, some changes have been made to the measurement model. An incorrect variable was not obtained by examining expression and residual values. Since most of the goodness of fit indices are within acceptable limits, it is not necessary to exclude any variables from the model. Covariance has been established only among some variables.

Table 28. Values of Post-Modified Measurement Model-NonResident

\begin{tabular}{|c|c|c|}
\hline Model Fit Index & $\begin{array}{c}\text { Model } \\
\text { Suitability } \\
\text { Value }\end{array}$ & $\begin{array}{l}\text { Measured } \\
\text { Value }\end{array}$ \\
\hline$x^{2} /$ d.f. & $\leq 5.00$ & 2.453 \\
\hline GFI (Goodness of Fit Index) & $\geq 0.90$ & 0.768 \\
\hline $\begin{array}{l}\text { AGFI (Adjusted Goodness of Fit } \\
\text { Index) }\end{array}$ & $\geq 0.80$ & 0.731 \\
\hline NFI (Normed Fit Index) & $\leq 0.90$ & 0.847 \\
\hline RFI (Relative Fit Index) & $\geq 0.90$ & 0.833 \\
\hline CFI (Comparative Fit Index) & $\geq 0.90$ & 0.902 \\
\hline $\begin{array}{l}\text { RMR (Root Mean Square } \\
\text { Residual) }\end{array}$ & $0-1$ & 0.057 \\
\hline $\begin{array}{l}\text { RMSEA (Root Mean Square } \\
\text { Error of Approximation) }\end{array}$ & $0.05-0.08$ & 0.077 \\
\hline
\end{tabular}

The model $x^{2} /$ d.f. value (2.453) is sensitive to sample size. Although an acceptable fit is mentioned in the fit index value when checking these index values, they slightly below the expected values when it comes to other values. As a result, it will not be possible to mention complete construct validity.

For the model, $x^{2} /$ d.f., GFI, AGFI, NFI, RMSEA values are not considered suitable. Therefore, some changes have been made to the measurement model. An incorrect variable was not obtained by examining expression and residual values. B04, B10 and B14 questions were removed from the analysis considering the standardized regression weights values, and covariance was created among some variables by checking at the covariance values under the modification indices heading.

Table 29. Values of the Measurement Model-Resident

\begin{tabular}{|c|c|c|}
\hline Model Fit Index & $\begin{array}{c}\text { Model } \\
\text { Suitability } \\
\text { Value }\end{array}$ & $\begin{array}{c}\text { Measured } \\
\text { Value }\end{array}$ \\
\hline $\mathrm{x}^{2} /$ d.f. & $\leq 5.00$ & 10.617 \\
\hline GFI (Goodness of Fit Index) & $\geq 0.90$ & 0.788 \\
\hline $\begin{array}{l}\text { AGFI (Adjusted Goodness of Fit } \\
\text { Index) }\end{array}$ & $\geq 0.80$ & 0.751 \\
\hline NFI (Normed Fit Index) & $\leq 0.90$ & 0.923 \\
\hline RFI (Relative Fit Index) & $\geq 0.90$ & 0.915 \\
\hline CFI (Comparative Fit Index) & $\geq 0.90$ & 0.930 \\
\hline $\begin{array}{l}\text { RMR (Root Mean Square } \\
\text { Residual) }\end{array}$ & $0-1$ & 0.059 \\
\hline $\begin{array}{l}\text { RMSEA (Root Mean Square } \\
\text { Error of Approximation) }\end{array}$ & $0.05-0.08$ & 0.085 \\
\hline
\end{tabular}

Table 30. Values of Post-Modified Measurement Model-

\begin{tabular}{lcc}
\multicolumn{2}{c}{ Resident } \\
\hline Model Fit Index & $\begin{array}{c}\text { Model } \\
\text { Suitability } \\
\text { Value }\end{array}$ & $\begin{array}{c}\text { Measured } \\
\text { Value }\end{array}$ \\
& $\leq 5.00$ & 4.966 \\
$\begin{array}{l}\mathbf{x}^{2} / \text { d.f. } \\
\text { GFI (Goodness of Fit Index) }\end{array}$ & $\geq 0.90$ & 0.911 \\
$\begin{array}{l}\text { AGFI (Adjusted Goodness of Fit } \\
\text { Index) }\end{array}$ & $\geq 0.80$ & 0.890 \\
NFI (Normed Fit Index) & $\leq 0.90$ & 0.966 \\
RFI(Relative Fit Index) & $\geq 0.90$ & 0.961 \\
$\begin{array}{l}\text { CFI(Comparative Fit Index) } \\
\text { RMR (Root Mean Square }\end{array}$ & $\geq 0.90$ & 0.973 \\
$\begin{array}{l}\text { Residual) } \\
\text { RMSEA (Root Mean Square } \\
\text { Error of Approximation) }\end{array}$ & $0.05-0.08$ & 0.049 \\
\hline
\end{tabular}

The model $\mathrm{x}^{2} /$ d.f. value (4.966) is sensitive to sample size. Although an acceptable fit is mentioned in the fit index value when checking these index values, they slightly below the expected values when it comes to other values. As a result, it will not be possible to mention complete construct validity.

\section{DISCUSSION}

Changing world standards with globalization have also affected the economies of the country. In the changing and developing economic conditions, sports are also developing and increasing their position in the sector day by day. Sport is positively affected as a result of developments in the world. At the same time, it has created its industry and has become an essential sector in itself due to its contribution to the growth values in the country's economies, from its former position where other industrial sectors are sub-sectors. Sports has taken an essential place in the world market today.

Today, sports have become an activity with economic potential. It has taken a great place in the tourism and media fields of the countries, especially in recent years. For this reason, it has been one of the crucial elements of both economic and social life. Therefore, it has a complementary relationship with other sectors. Sport has taken a prominent place not only in sports events but also in activities around sports events by staying out of the fields. Sports activities have become a sector that includes advertising, promotion and promotional activities. In this regard, 
investments in sports organizations and athletes have increased day by day. This led to a further understanding of the economic effects of sports. Shortly, countries are making more significant efforts to bring large sports organizations to their countries, as they are aware of the contribution of the sports sector to the GNP of the country's economies. In the study, the satisfaction of participants of the Istanbul Marathon is compared with the cost items spent during the organization. As a result of the survey results, the opinions of non-resident and resident participants are compared.

Non-resident participants mostly chose the "I would like to recommend the event to someone else" variable, whereas resident participants preferred the "I was satisfied with the event operation process" variable. While the non-resident participants selected the variables "I was satisfied with the event operation process", "I was pleased with the attitude and behavior of the officials", "I was satisfied with security services", resident participants selected "I was pleased with the attitude and behavior of the officials" and "I will participate again". Non-resident participants determined the most necessary elements of the organization's cost items as "Start and finish organizations are required", while resident participants preferred the "Timing System is required". Moreover, other answers of the non-resident participants are respectively as "Press conference organizations are required", "Timing System is required", "Bib number is required" variables. In contrast, resident participants answers are respectively as "Sponsorship activities are required", "Start and finish organizations are required", "Free transportation to the start area" is required.

While the variable "I would like to recommend the event to someone else" was the highest rate of the nonresident participants with the $76 \%$, the variable "I will participate again" was the lowest rate of the nonresident with 42\%. World Marathons (29) which is an online marathon registration service provider, found that the primary motivation for the runners to participate in the Event compared to $66.30 \%$ was to discover new cities through Marathon. This study similar to the survey of the World Marathons. In resident participants, the variable "I was satisfied with the event operation process" was the highest rate with the $87.4 \%$, while the variable "I was satisfied with toilet facilities" was the lowest rate of the resident with $44 \%$. When we compare the resident and non-resident groups in terms of participant satisfaction, the most dominant first three variables in both groups were the essential factors in both groups. Toilet services were the most satisfying service in both groups. The dissatisfaction of foreigners regarding the registration process of the Event may be the payment problems experienced during online registration. The variable of "I will participate again" is not dissatisfaction, because the participants coming from abroad to participate in the Event like sports tourism. Organizers should ensure that non-resident participants have good event experience and recommend the Event to other participants.

The highest expenditure items of the Istanbul Marathon organized by the Istanbul Metropolitan Municipality were also discussed. The most dominant variable among non-resident participants in the cost items in the event process was the start and finish organizations with $82 \%$. The other two dominant factors were press conference and chip services. Resident participants were found to chip service with $91 \%$ of the dominant group. Although the chip service is less costly than the installation of the start and finish organizations, this service is a fundamental issue for the resident to make the race fair and transparent. Therefore, it is expected that this variable will be the dominant variable for resident people.

Prize money is the least dominant variable in the cost process in both non-resident and resident groups. In prize money, it has $47 \%$ in the non-resident group and $49 \%$ in the resident group. Çetin (30)'s study indicates that the highest factor motivating triathletes' participation in the Ironman Events were life satisfaction and achievement perception. Similarly, Çetin and Ozman's (3) study found that there was a significant relationship between the sub-dimensions of the self-esteem, psychological coping and life meaningfulness with male ultra-marathoners.

Similarly, bags distribution appeared as the second-lowest variable in both groups. Race bags service in a non-resident group has 58\% importance, while the resident group has $74.5 \%$. Even though the participants are considered to have a lower importance than other variables, the organizer distributes these bags to the participants both for luggage bus operation and safety measures. However, the organizer may implement a cost leadership strategy for this cost item. In general terms, the sponsorship activities and press conference variables placed similar importance when the costs of both groups in the marathon process are analyzed. Therefore, the perceived costs of the organizer by both groups are consistent with the two variables above.

While the answers about sponsorship have the third-lowest density with $59 \%$ in the non-resident group and the second highest variable in the resident group with $90 \%$, generally, this kind of sports events are carried out by private sector, and public support may not be vital for foreign participants. Because sporting events are often done with public support in Turkey, the perception of citizens can be regarded as usual. The press conference was determined as the second-highest variable in non-resident with $80 \%$, while it was the third most crucial cost item in resident with $75 \%$. It can be concluded that they attach more importance to the publications published in the press 
about the events that the participants will participate abroad. As a result, cost items spent within the scope of the Istanbul Marathon were evaluated by both resident and non-resident participants; it was determined that the lowest factor in both groups was the prize money. The requirement of all other cost items perceived by both resident and non-resident participants between $59 \%$ and $91 \%$.

\section{CONCLUSION}

In conclusion, the cost items spent within the scope of the Istanbul Marathon were evaluated by both resident and non-resident participants; it was determined that the lowest factor in both groups was the prize money. The requirement of all other cost items perceived by both resident and non-resident participants is over 50\%. Therefore, the local government-sponsored the Marathon was supported by both non-resident and resident participants, where the principal expenditure items were required.

\section{APPLICABLE REMARKS}

- Local governments have a responsibility to their citizens-taxers. Therefore, it is recommended for local governments to analyze spending for sports events in terms of transparency and accountability with similar studies.

- Non-resident participants consider mass events as sports tourism activities. Therefore, local administrations can make an extra contribution to the local economy by promoting mass sports events in international markets in cooperation with tourism agencies.

- Organizers need to set their priorities to determine prize money in the scope of elite athletes and recreational runners.

- Local governments should continue to support mass sports events both as sponsors and organizers.

\section{REFRENCES}

1. Hoffman MD, Ong JC, Wang G. Historical analysis of participation in $161 \mathrm{~km}$ ultramarathons in North America. Int J Hist Sport. 2010;27(11):1877-1891. doi: 10.1080/09523367.2010.494385 pmid: 20684085

2. Hoffman MD, Krouse R. Ultra-obligatory running among ultramarathon runners. Res Sports Med. 2018;26(2):211221. doi: 10.1080/15438627.2018.1431533 pmid: 29378427

3. Çetin A, Özman C. Runners' motivational dimensions for participation in the ultra-marathon events and the comparison of these factors with their life satisfaction and success perceptions Spormetre Beden Eğitimi ve Spor Bilimleri Dergisi. 2019;17(2):177-187.

4. Gratton C, Shibli S, Coleman R. Sport and Economic Regeneration in Cities. Urb Stud. 2016;42(5-6):985-999. doi: 10.1080/00420980500107045

5. Papanikos GT. The real exchange rate of euro and Greek economic growth. J Econ Asymmetries. 2015;12(2):100109. doi: 10.1016/j.jeca.2015.04.002

6. Gibson HJ. Sport Tourism: A Critical Analysis of Research. Sport Manage Rev. 1998;1(1):45-76. doi: 10.1016/s1441-3523(98)70099-3

7. Ross D. Developing Sports Tourism. An eGuide for Destination Marketers and sports Events Planners, National Laboratory for Tourism and eCommerce. University of Ilinois at Urbana Champaign: University of Ilinois at Urbana Champaign; 2001.

8. Robinson T, Gammon S. A question of primary and secondary motives: revisiting and applying the sport tourism framework. J Sport Tourism. 2007;9(3):221-233. doi: 10.1080/1477508042000320223

9. Kasimati E. Economic aspects and the Summer Olympics: a review of related research. Int J Tourism Res. 2003;5(6):433-444. doi: 10.1002/jtr.449

10. Matheson V. Mega-Events: The effect of the world's biggest sporting events on local, regional, and national economies. Int Assoc Sports Econ. 2006.

11. Kim W, Jun HM, Walker M, Drane D. Evaluating the perceived social impacts of hosting large-scale sport tourism events: Scale development and validation. Tourism Manage. 2015;48:21-32. doi: 10.1016/j.tourman.2014.10.015

12. Kaplanidou K, Karadakis K, Gibson H, Thapa B, Walker M, Geldenhuys S, et al. Quality of Life, Event Impacts, and Mega-Event Support among South African Residents before and after the 2010 FIFA World Cup. J Trav Res. 2013;52(5):631-645. doi: 10.1177/0047287513478501

13. Roche S, Spake DF, Joseph M. A model of sporting event tourism as economic development. Sport Busin Manage Int J. 2013;3(2):147-157. doi: 10.1108/20426781311325078

14. Wilson JK, Siegfried JJ. Who Sits in Australia's Grandstands? J Sports Econ. 2016;19(3):389-397. doi: $10.1177 / 1527002516656728$

15. Castro SBEd, Starepravo FA, Coakley J, Souza DLd. Mega sporting events and public funding of sport in Brazil (2004-2011). Leis Stud. 2015;35(3):369-386. doi: 10.1080/02614367.2015.1037789

16. Mitchell H, Stewart MF. What should you pay to host a party? An economic analysis of hosting sports megaevents. Appl Econ. 2015;47(15):1550-1561. doi: 10.1080/00036846.2014.1000522

17. Conejo RA, Pino JB, Dominguez JFC, Guerrero PR. The economic impact of football on the regional economy. Int J Sport Manage Mark. 2007;2(5/6). doi: 10.1504/ijsmm.2007.013961 
18. Turco DM. Host Residents' Perceived Social Costs and Benefits Toward a Staged Tourist Attraction. J Trav Tourism Mark. 1997;7(1):21-30. doi: 10.1300/J073v07n01_02

19. Preuss H. Calculating the regional economic impact of the olympic games. Eur Sport Manage Q. 2004;4(4):234253. doi: 10.1080/16184740408737479

20. Frechtling DC, Horváth E. Estimating the Multiplier Effects of Tourism Expenditures on a Local Economy through a Regional Input-Output Model. J Trav Res. 2016;37(4):324-332. doi: 10.1177/004728759903700402

21. Leontief W. Input-Output Analysis. The New Palgrave Dictionary of Economics; 1987. p. 1-8.

22. Kim MK, Kim S-K, Park J-A, Carroll M, Yu J-G, Na K. Measuring the economic impacts of major sports events: the case of Formula One Grand Prix (F1). Asia Pacific J Tourism Res. 2016;22(1):64-73. doi: 10.1080/10941665.2016.1176061

23. Aydoğuş PDO, Değer APDÇ, Tunalı Çalışkan E, Gürel Günal Gl. Regional Input-Output Analysis of A MegaEvent: Possible Impact of EXPO on Izmir Economy. Anadolu Üniversitesi Sosyal Bilimler Dergisi. 2015;15(2). doi: $10.18037 /$ ausbd.62788

24. Li S, Jago L. Evaluating economic impacts of major sports events - a meta analysis of the key trends. Curr Issu Tourism. 2013;16(6):591-611. doi: 10.1080/13683500.2012.736482

25. Turan İ, Şimşek Ü, Aslan H. The Use and Analysis of Likert Scales and Likert-Type Items in Educational Research. Sakarya Üniversitesi Eğitim Fakültesi Dergisi. 2015(30):188.

26. Mert M. Yatay Kesit Veri Analizi Bilgisayar Uygulamaları. Ankara: Detay Yayıncılık; 2016.

27. Kalaycı Ş. SPSS Uygulamalı Çok Değişkenli İstatistik Teknikleri. 7. bsk: Asil Yayın Dağıtım Ankara, Turkey; 2016.

28. Büyüköztürk Ş. Faktör analizi: Temel kavramlar ve ölçek geliştirmede kullanımı. Kuram ve uygulamada eğitim yönetimi. 2002;32(32):470-483.

29. Presentations erbc 20192019 [cited 2020]. Available from: http://www.erbc2019.com/presentations.html.

30. Çetin A. Triathletes' Motivational Dimensions for Participation in Ironman, and Comparison of these Factors with Their Life Satisfaction and Achievement Perceptions. Int J Hum Mov Sports Sci. 2019;7(3):43-50. doi: 10.13189/saj.2019.070301 